\title{
Comparison of Serum 25-Hydroxyvitamin D Levels in Patients With Malignant and Benign Gynaecological Disease
}

\author{
LAURA KOLNSBERG ${ }^{1}$, MARION RIFFELMANN ${ }^{2}$ and MICHAEL FRIEDRICH ${ }^{1}$ \\ ${ }^{1}$ Department of Gynaecology and Obstetrics, Helios Hospital Krefeld, Krefeld, Germany; \\ ${ }^{2}$ Institute of Laboratory Medicine, Helios Hospital Krefeld, Krefeld, Germany
}

\begin{abstract}
Background/Aim: Many studies have shown an antiproliferative, anti-inflammatory, anti-angiogenetic, and apoptosis-inducing effect of Vitamin D. A vitamin D deficiency has been associated with an increased risk for different types of cancer. This study examined vitamin D 25(OH)D levels in gynaecological cancers in comparison with benign gynaecological diseases. Patients and Methods: Serum $25(\mathrm{OH}) \mathrm{D}$ levels in 688 gynaecological patients (488 with malignant, 200 with a benign gynaecological disease) were assayed between 2009 and 2015 using an electrochemiluminescence immunoassay. Results: In total, the 25(OH)D levels in cancer patients were lower, but not significantly lower than those in cancer-free patients. Significant results were shown regarding seasonal effects for patients with breast-, endometrial and ovarian cancer. No significant effects occurred with regard to menopause status, nicotine, or grade in relation to $25(\mathrm{OH}) \mathrm{D}$ levels. Conclusion: $25(\mathrm{OH}) \mathrm{D}$ levels seem to influence gynaecological cancers.
\end{abstract}

The incidence of breast cancer is $100 / 100,000$ women in Germany per year, with the highest incidence seen between 45 and 75 years of age (1). The incidence increases each year because of early diagnosis via screening and thus, there is a shift to a higher frequency of early stage diseases (1). The cumulative lifetime risks amount to 13 percent for acquiring the disease and 5 percent for dying from the disease (2). As such, breast cancer is the most frequent cancer type in German women (3).

Vulvar cancer is a rare disease, $3 \%$ to $5 \%$ of all genital carcinomas are induced through vulvar cancer, with an

Correspondence to: Laura Kolnsberg, Department of Gynaecology and Obstetrics, Helios Hospital Krefeld, Lutherplatz 40, 47805 Krefeld, Germany. Tel: +49 2151322201, Fax: +49 2151322220, e-mail: laura.kolnsberg@helios-kliniken.de

Key Words: Vitamin D, gynaecological cancers, seasonal influence, menopause status, age, nicotine abuse, grade. incidence of 1.5-4 per 100,000 / women in Germany $(2,4)$. Endometrial cancer, with 11,370 new cases per year, is considered as the fourth most common malignant disease in German women (5). There are two major types of endometrial cancer, Type I, called endometroid adenocarcinoma and Type II, non-endometroid endometrial cancer. Type I is the most frequent with about $80 \%$ occurrence, and is associated with estrogen exposure (6). The 5 -year overall survival rate of $82 \%$ is much higher than the $58 \%$ for Type II endometrial cancer (7).

Ovarian cancer is one of the sixth most frequent types of cancer in women, and has the highest mortality rate. The lifetime risk is about $1 \%$. The peak age of disease is at 60 years of age (between 50 and 70 years). Three-quarters of the patients are diagnosed at an advanced stage III or IV (8).

Cervical cancer occurs in 9 out of 100,000 women per year with a peak occurrence at the age of 53 years (between 40 and 59 years of age). Cervical precancerous lesions are present a hundred times more frequently at the age of 34 years (9).

Vitamin D is a lipophilic steroid hormone, which is synthesized in the liver from cholesterol. 7-dehydrocholesterol is metabolized to provitamin D3 by UV-B in the skin and is converted to cholecalciferol (Vitamin D3) $(10,11)$. In the liver, cholecalciferol is transformed into 25-hydroxycholecalciferol (25-OH-D3, calcidiol) which is the best indicator of the vitamin D status in the blood (12). 25-OH-D3 is transported via vitamin D Binding protein (DBP) to the kidney for its hydroxylation to the active form, 1,25 dihydroxycholecalciferol (calcitriol) (12). This transformation is under the control of phosphate. Low phosphate stimulates formation of calcitriol and vice versa. Calcitriol supports the enteral resorption from calcium and phosphate (13).

CYP27b1 is also found in other tissues like breast, prostate and colorectal and produces 1,25(OH)2D3. This binds to the vitamin $\mathrm{D}$ receptor, influences gene expression and supports proliferation and differentiation of cells (14, 15). In addition, an anti-carcinogenic effect of high vitamin D levels has been discovered $(16,17)$. 


\section{Patients and Methods}

This study's cohort consisted of 688 patients who received medical treatment at the Department of the Helios hospital Krefeld, Germany, from 2009 to 2015 . A total of 200 patients suffered from benign gynaecological disease and 488 had gynaecological cancers like endometrial, ovarian, vulvar, cervical and breast cancer. The patients were informed about the study and provided written consent for having blood samples taken and stored for scientific analysis. After written consent was obtained, an additional capillary blood sample was obtained and stored at the Institute of Hygiene and Laboratory Medicine at $-20^{\circ} \mathrm{C}$ until further analysis. The following points were examined from the patients clinical and pathology records: disease, malignant or benign, season of blood draw pre or post menopause age at blood draw, nicotine abuse, grading.

The 25(OH)D levels were analysed at the Institute of Hygiene and Laboratory Medicine with an electrochemiluminescence immunoassay. To compare the $25(\mathrm{OH})$ levels, different testing methods were used, e.g. Mann-Whitney $U$-test, Kruskal-Walliestest, Chi-square-tests and Spearman correlation. Differences with a $p$-value of less than 0.05 were defined as statistically significant The statistical analysis was performed with IBM SPSS Statistics 22, IBM Corp. Released 2013. IBM SPSS Statistics for Macintosh, Version 22.0. (IBM Corp. Armonk, NY, USA).

\section{Results}

The $25(\mathrm{OH}) \mathrm{D}$ average level of all 688 samples was $18.31 \pm 11.71$ $\mathrm{ng} / \mathrm{ml}$. Patients with benign disease had higher levels $(19.00 \pm 12.50 \mathrm{ng} / \mathrm{ml}$, median=17.20 ng/ml $)$ than patients with a carcinoma $(18.03 \pm 11.37 \mathrm{ng} / \mathrm{ml}$, median $=14.91 \mathrm{ng} / \mathrm{ml})$. However, there was no significant difference between these two groups (Mann-Whitney $U$-test: $\mathrm{U}=47389.50, \mathrm{z}=-0.60, p=0.551$ ).

Table I shows the different $25(\mathrm{OH}) \mathrm{D}$ levels for each group of patients. In the group of patients with benign disease, patients with endometriosis showed the highest $25(\mathrm{OH}) \mathrm{D}$ levels, while patients with complications during pregnancy had the lowest $25(\mathrm{OH}) \mathrm{D}$ levels. In the malignant group, patients with breast cancer had the highest levels and patients with cervical cancer had the lowest $25(\mathrm{OH}) \mathrm{D}$ levels.

Seasonal influence. 25(OH)D levels in patients from both groups were lowest in spring (benign: $14.27 \pm 12.60 \mathrm{ng} / \mathrm{ml}$, median=9.57 ng/ml; malignant: $14.42 \pm 9.76 \mathrm{ng} / \mathrm{ml}$, median=11.31 ng/ml). Highest levels were found in summer in patients with benign disease $(23.73 \pm 10.66 \mathrm{ng} / \mathrm{ml}$; median $=21.89 \mathrm{ng} / \mathrm{ml}$ ) as well as in cancer patients $(21.64 \pm 11.20 \mathrm{ng} / \mathrm{ml}$, median $=21.10 \mathrm{ng} / \mathrm{ml})$.

The significance of seasonal effects for both groups were calculated with the Mann-Whitney $U$-test. Significant differences in the levels of $25(\mathrm{OH}) \mathrm{D}$ in benign disease were revealed by comparing spring/summer, spring/autumn, winter/summer, spring/winter, and autumn/summer. Almost the same results were described in malignant disease, however, comparison of spring/winter and autumn/winter did not show a significant difference (Table II).
Table I. 25(OH)D levels in different benign gynaecological diseases and cancers.

\begin{tabular}{llll}
\hline & Disease & $\begin{array}{c}\text { MW } \pm \text { SD } \\
(\mathrm{ng} / \mathrm{ml})\end{array}$ & $\begin{array}{c}\text { Median } \\
(\mathrm{ng} / \mathrm{ml})\end{array}$ \\
\hline Benign & Bleeding disorders & $20.37 \pm 12.87$ & 19.36 \\
$(\mathrm{~N}=200)$ & Benign findings of the ovaries & $19.41 \pm 12.40$ & 17.04 \\
& Postmenopausal bleeding & $20.00 \pm 10.94$ & 23.93 \\
& Benign findings of the & $17.29 \pm 12.22$ & 15.14 \\
& Endometriosis & $27.05 \pm 16.85$ & 23.64 \\
& Pregnancy complications & $16.59 \pm 10.02$ & 15.44 \\
Malignant & Endometrial cancer & $15.81 \pm 8.35$ & 13.53 \\
& Ovarian cancer & $16.13 \pm 9.69$ & 14.58 \\
& Vulvar cancer & $18.61 \pm 14.61$ & 11.47 \\
& Breast cancer & $18.69 \pm 11.76$ & 15.57 \\
& Cervical cancer & $13.59 \pm 6.63$ & 10.55 \\
\hline
\end{tabular}

Table II. Examination of significant effects: $25(\mathrm{OH}) D$ levels in benign and malignant diseases in relation to seasons.

\begin{tabular}{lcc}
\hline & 25(OH)D-levels & Mann-Whitney $U$-test \\
\hline Benign & Spring $<$ Summer & $\mathrm{U}=565.00 \mathrm{z}=-4.72, p<0.001$ \\
& Spring $<$ Autumn & $\mathrm{U}=1148.50, \mathrm{z}=-2.83, p=0.005$ \\
& Winter $<$ Summer & $\mathrm{U}=563.500, \mathrm{z}=-2.67, p=0.008$ \\
& Spring $<$ Winter & $\mathrm{U}=635.00, \mathrm{z}=-2.26, p=0.024$ \\
& Spring $<$ Summer & $\mathrm{U}=1156.00, \mathrm{z}=-2.50, p=0.012$ \\
& Winter/Autumn & $\mathrm{U}=1072.00, \mathrm{z}=-0.47, p=0.636$ \\
Malignant & Spring $<$ Summer & $\mathrm{U}=3604.50, \mathrm{z}=-5.63, p<0.001$ \\
& Spring $<$ Autumn & $\mathrm{U}=4573.00, \mathrm{z}=-5.27, p<0.001$ \\
& Winter $<$ Summer & $\mathrm{U}=4746.00, \mathrm{z}=-4.65, p<0.001$ \\
& Spring/Winter & $\mathrm{U}=7586.50, \mathrm{z}=-0.86, p=0.390$ \\
& Autumn/Summer & $\mathrm{U}=6241.50, \mathrm{z}=-0.97, p=0.330$ \\
& Winter $<$ Autumn & $\mathrm{U}=5964.50, \mathrm{z}=-4.25, p<0.001$ \\
\hline
\end{tabular}

Table III. Comparison of 25(OH)D-levels in different seasons.

\begin{tabular}{lcc}
\hline & $\begin{array}{c}\text { 25(OH)D-levels in quartiles: } \\
\text { Comparison seasons }\end{array}$ & Mann-Whitney $U$-test \\
& Spring $<$ Summer & $\mathrm{U}=580.00, \mathrm{z}=-4.78, p<0.001$ \\
Benign & Spring $<$ Autumn & $\mathrm{U}=1255.00, \mathrm{z}=-2.34, p=0.019$ \\
& Winter $<$ Summer & $\mathrm{U}=552.50, \mathrm{z}=-2.90, p=0.004$ \\
& Spring $<$ Winter & $\mathrm{U}=693.50, \mathrm{z}=-1.84, p=0.066$ \\
& Autumn $<$ Summer & $\mathrm{U}=1115.00, \mathrm{z}=-2.847, p=0.004$ \\
& Winter/Autumn & $\mathrm{U}=1096.00, \mathrm{z}=-0.31, p=0.756$ \\
Malignant & Spring $<$ Summer & $\mathrm{U}=3803.00, \mathrm{z}=-5.40, p<0.001$ \\
& Spring $<$ Autumn & $\mathrm{U}=4976.50, \mathrm{z}=-4.71, p<0.001$ \\
& Winter $<$ Summer & $\mathrm{U}=4777.50, \mathrm{z}=-4.74, p<0.001$ \\
& Spring/Winter & $\mathrm{U}=7845.00, \mathrm{z}=-0.439, p=0.661$ \\
& Autumn/Summer & $\mathrm{U}=6186.50, \mathrm{z}=-1.13, p=0.260$ \\
& Winter $<$ Autumn & $\mathrm{U}=6169.00, \mathrm{z}=-4.04, p<0.001$ \\
\hline
\end{tabular}


Table IV. Comparison of 25(OH)D levels in gynaecological cancer and endometriosis in relation to seasons.

\begin{tabular}{lcc}
\hline $25(\mathrm{OH}) \mathrm{D}$-levels & Entity & Mann-Whitney $U$-test \\
\hline Spring & Endometrial cancer & $\mathrm{U}=11.00, \mathrm{z}=-2.21, p=0.027$ \\
$<$ & Breast cancer & $\mathrm{U}=1965.00, \mathrm{z}=-4.86, p<0.001$ \\
Summer & Ovarian cancer & $\mathrm{U}=5.00, \mathrm{z}=-2.98, p=0.003$ \\
& Other entities & No significant differences \\
& & $p>0.604$ \\
Spring & Breast cancer & $\mathrm{U}=2294.50, \mathrm{z}=-4.75, p<0.001$ \\
$<$ & Ovarian cancer & $\mathrm{U}=4.00, \mathrm{z}=-2.94, p=0.003$ \\
Autumn & Other entities & No significant differences \\
& & $p>0.139$ \\
Spring/Winter & Other entities & No significant differences \\
& & $p>0.127$ \\
Summer & Endometrial cancer & $\mathrm{U}=14.00, \mathrm{z}=-2.41, p=0.016$ \\
$>$ & Other entities & No significant differences \\
Autumn & & $p>0.102$ \\
Summer & Breast cancer & $\mathrm{U}=2933.00, \mathrm{z}=-4.34, p<0.001$ \\
$>$ & Other entities & No significant differences \\
Winter & Breast cancer & $\mathrm{U}=3377.50, \mathrm{z}=-4.29, p<0.001$ \\
Autumn & Other entities & No significant differences \\
$>$ & & $p>0.103$ \\
Winter & & \\
\hline & & \\
& &
\end{tabular}

The 25(OH)D levels were classified in quartiles: $1 \mathrm{st}$ quartile $\leq 9.59 \mathrm{ng} / \mathrm{ml}$, 2nd quartile $9.60-15.49 \mathrm{ng} / \mathrm{ml}, 3 \mathrm{nd}$ quartile $15.50-24.24 \mathrm{ng} / \mathrm{ml}$, and 4 th quartile $\geq 24.25 \mathrm{ng} / \mathrm{ml}$.

The comparison of $25(\mathrm{OH}) \mathrm{D}$ levels in quartiles for the different seasons showed significant effects as per Table III. Mann-Whitney- $U$-test revealed significant differences for spring/summer, spring/autumn, winter/summer and autumn/summer in the benign group. In the cancer group significant effects were described for spring/summer, spring/autumn, winter/summer and winter/autumn (Table III).

The examination of $25(\mathrm{OH}) \mathrm{D}$ levels in the different carcinomas and endometriosis in relation to seasons indicated significant outcomes especially for breast, ovarian and endometrial cancer with the Mann-Whitney $U$-test: Spring/summer: Endometrial cancer: $\mathrm{U}=11.00, \mathrm{z}=-2.21$, $p=0.027$, Breast cancer: $\mathrm{U}=1965.00, \mathrm{z}=-4.86, p<0.001$, ovarian cancer: $\mathrm{U}=5.00, \mathrm{z}=-2.98, p=0.003$. Spring/autumn: breast cancer: $\mathrm{U}=2294.50, \mathrm{z}=-4.75, p<0.001$, ovarian cancer: $\mathrm{U}=4.00, \mathrm{Z}=-2.94, p=0.003$. Summer/autumn: endometrial cancer: $\mathrm{U}=14.00, \quad \mathrm{z}=-2.41, \quad p=0.016$ summer/winter: breast cancer: $U=2933.00, \quad z=-4.34$, $p<0.001$ autumn/winter: breast cancer: $\mathrm{U}=3377.50, \mathrm{z}=-$ $4.29, p<0.001$ (Table IV).

With the use of the Mann-Whitney $U$-test significant differences in $25(\mathrm{OH}) \mathrm{D}$ levels in quartiles in relation to seasons and entities were examined. Especially patients with breast cancer showed significant associations (Table V).
Table V. Comparison of 25(OH)D levels in quartiles in gynaecological cancer and endometriosis in relation to seasons.

\begin{tabular}{|c|c|c|}
\hline $\begin{array}{l}25(\mathrm{OH}) \mathrm{D} \text { levels- } \\
\text { Quartiles }\end{array}$ & Entity & Mann-Whitney $U$-test \\
\hline Spring & Endometrial cancer & $\mathrm{U}=9.00, \mathrm{z}=-2.50, p=0.013$ \\
\hline$<$ & Breast cancer & $\mathrm{U}=2078.00, \mathrm{z}=-4.66, p<0.001$ \\
\hline Summer & $\begin{array}{l}\text { Ovarian cancer } \\
\text { Other entities }\end{array}$ & $\begin{array}{c}\mathrm{U}=8.50, \mathrm{z}=-2.76, p=0.006 \\
\text { No significant differences } \\
p>0.604\end{array}$ \\
\hline Spring & Breast cancer & $\mathrm{U}=2531.50, \mathrm{z}=-4.20, p=0.000$ \\
\hline$<$ & Ovarian cancer & $\mathrm{U}=8.50, \mathrm{z}=-2.59, p=0.010$ \\
\hline Autumn & Other entities & $\begin{array}{l}\text { No significant differences } \\
\qquad p>0.080\end{array}$ \\
\hline Spring/Winter & Other entities & $\begin{array}{l}\text { No significant differences } \\
\qquad p>0.081\end{array}$ \\
\hline Summer/ & Endometrial cancer & $\mathrm{U}=21.00 \mathrm{z}=-1.96 p=0.050$ \\
\hline Autumn & Other entities & $\begin{array}{l}\text { No significant differences } \\
\qquad p>0.152\end{array}$ \\
\hline Summer & Breas & $\mathrm{U}=2897.00, \mathrm{z}=-4.58, p<0.001$ \\
\hline$>$ & Other entities & No significant differences \\
\hline Winte & & $p>0.129$ \\
\hline Autumn & Breast cancer & $\mathrm{U}=3486.50, \mathrm{z}=-4.16, p<0.001$ \\
\hline & Other entities & No significant differences \\
\hline Winter & & $p>0.109$ \\
\hline
\end{tabular}

Influence of menopause status. The $25(\mathrm{OH}) \mathrm{D}$ levels in pre- and post-menopausal patients did not show a significant association neither in the benign ( $\mathrm{U}=3244.50, \mathrm{z}=0.22, p=0.826)$ nor in the malignant group $(\mathrm{U}=17701.50, \mathrm{z}=-0.45, p=0.964)$.

Same results applied to the examination of quartiles. No significant difference was found between pre- or postmenopausal patients $(\mathrm{U}=53001.50, \mathrm{z}=-0,60, p=0.546)$ and differentiation of benign or malignant disease.

Regarding the different carcinomas and endometriosis, the Mann-Whitney $U$-test found no statistically significant association between 25(OH)D levels and menopause status (Endometriosis: $\mathrm{U}=2.00, \mathrm{z}=-1.28, p=0.201$, endometrial cancer: $\mathrm{U}=62.00, \mathrm{z}=-0.29, p=0.775$, breast cancer: $\mathrm{U}=9490.50, \mathrm{z}=-0.16$, $p=0.877$, ovarian cancer: $\mathrm{U}=51.00, \mathrm{z}=-0.26, p=0.776$, vulvar cancer: $\mathrm{U}=25.00, \mathrm{z}=0.05, p=0.958$, cervical cancer: $\mathrm{U}=59.50$, $\mathrm{z}=-1.08, p=0.280)$. The examination of $25(\mathrm{OH}) \mathrm{D}$ levels in quartiles in relation to menopause status for different carcinomas did not show a significant result $(p>0.26)$ (Table VI).

Influence of age. Spearman correlation showed a significant association between $25(\mathrm{OH}) \mathrm{D}$ levels and age in the malignant group $\left(\mathrm{r}_{\mathrm{s}}=-0.096, p=0.034\right)$ but not in the benign group ( $r s=0.013, p=0.854$ ). After division into quartiles, a significant correlation to age was found in patients with gynaecological cancer $\left.r_{s}=-0.11, p=0.015\right)$. There was no statistically significant effect after classification by age, over and under 50 years. 
Table VI. Significance of $25(\mathrm{OH})$ D levels and $25(\mathrm{OH})$ D levels in quartiles in gynaecological cancers and endometriosis in relation to menopause status (Mann-Whitney U-test).

\begin{tabular}{lcc}
\hline Entity & $25(\mathrm{OH}) \mathrm{D}-\mathrm{levels}$ & 25(OH)D-levels in quartiles \\
\hline Endometriosis & $\mathrm{U}=2.00, \mathrm{z}=-1.28, p=0.201$ & $\mathrm{U}=3.50, \mathrm{z}=-1.06, p=0.290$ \\
Endometrial cancer & $\mathrm{U}=62.00, \mathrm{z}=-0.29, p=0.775$ & $\mathrm{U}=57.00, \mathrm{z}=-0.54, p=0.589$ \\
Breast cancer & $\mathrm{U}=9490.50, \mathrm{z}=-0.16, p=0.877$ & $\mathrm{U}=9400.00 \mathrm{z}=-0.28, p=0.779$ \\
Ovarian cancer & $\mathrm{U}=51.00, \mathrm{z}=-0.26, p=0.776$ & $\mathrm{U}=46.00, \mathrm{z}=-0.59, p=0.555$ \\
Vulvar cancer & $\mathrm{U}=25.00, \mathrm{z}=0.05, p=0.958$ & $\mathrm{U}=23.00, \mathrm{z}=-0.28, p=0.779$ \\
Cervical cancer & $\mathrm{U}=59.50, \mathrm{z}=-1.08, p=0.280$ & $\mathrm{U}=60.00, \mathrm{z}=-1.13, p=0.260$ \\
\hline
\end{tabular}

Especially breast cancer patients had a significant association with age (Spearman correlation $r_{s}=-0.15$, $p=0.004)$. This result was also found after division into quartiles (Spearman correlation $r_{s}=-0.16, p=0.002$ ). Other entities did not show a correlation. Also, after classification of patients into over and under 50 years of age, no significant effects were found with the Mann-Whitney $U$ test $(p>0.194)$.

Influence of nicotine abuse. There was no significant association between $25(\mathrm{OH}) \mathrm{D}$ levels and nicotine abuse either for patients in the malignant group ( $\mathrm{U}=13917.00, \mathrm{z}=-1.18$, $p=0.240)$ or for patients in the benign gynaecological disease group ( $\mathrm{U}=3653.50, \mathrm{z}=-0.66, p=0.240)$. Table VII shows the average standard deviation and median of $25(\mathrm{OH}) \mathrm{D}$ levels in both groups of nicotine consumption, yes or no.

The classification into quartiles did not reveal a difference, as no significant results were found in the Mann-Whitney $U$ test for benign disease $(\mathrm{U}=3738.00, \mathrm{z}=-0.43, p=0.665)$ or cancer patients $(\mathrm{U}=14045.00, \mathrm{z}=-1.08, p=0.279)$.

Examinations of each cancer group and of endometriosis did not reveal any significant association in relation to nicotine abuse ( $p>0.184$, respectively; $p>0.253)$.

Influence of grade. In this study, 488 patients had cancer, out of which 87 had a Grade 1 cancer [25(OH)D levels $17.39 \pm 10.51 \mathrm{ng} / \mathrm{ml}$ (median=14.83 ng/ml)]. The 25(OH)D levels in 236 patients with Grade 2 cancer were $18.98 \pm 12.32$ $\mathrm{ng} / \mathrm{ml}$ (median=15.86 ng/ml) and in 164 patients with Grade 3 -cancer were $17.04 \pm 10.31 \mathrm{ng} / \mathrm{ml}$ (median=14.13 ng/ml). One patient had a Grade 4 cancer $(10.08 \pm 0 \mathrm{ng} / \mathrm{ml}$ (median=14.91 ng/ml). Spearman correlation did not show a significant association between the grade of the cancer and 25(OH)D levels $\left(\mathrm{r}_{\mathrm{s}}=-0.31, p=0.490\right)$. Also, following classification into quartiles no significant differences were observed (Spearman correlation: $\mathrm{r}_{\mathrm{s}}=-0.035, p=0.442$ ).

A significant association of different gynaecological cancer types with grading and $25(\mathrm{OH}) \mathrm{D}$ level was not observed. The classification into quartiles also showed no significant differences (Table VIII).
Table VII. 25(OH)D levels in patients with benign and malignant gynaecological diseases in relation to nicotine consumption.

\begin{tabular}{lccc}
\hline & $\begin{array}{c}\text { Nicotine } \\
\text { abuse }\end{array}$ & $\begin{array}{c}\text { MW } \pm \text { SD } \\
(\mathrm{ng} / \mathrm{ml})\end{array}$ & $\begin{array}{c}\text { Median } \\
(\mathrm{ng} / \mathrm{ml})\end{array}$ \\
\hline Benign findings & Yes & $20.46 \pm 13.86$ & 17.32 \\
& No & $18.56 \pm 11.82$ & 17.23 \\
Malignant findings & Yes & $17.36 \pm 12.30$ & 13.91 \\
& No & $17.99 \pm 10.79$ & 15.04 \\
\hline
\end{tabular}

Table VIII. Significance of 25(OH)D levels and 25(OH)D levels in quartiles in dependence of grade for different gynaecological cancers (Spearman Rho coefficient).

\begin{tabular}{lcc}
\hline Entity & $\begin{array}{c}25(\mathrm{OH}) \mathrm{D} \\
\text { levels }\end{array}$ & $\begin{array}{c}25(\mathrm{OH}) \mathrm{D}-\text { levels } \\
\text { in quartiles }\end{array}$ \\
\hline $\begin{array}{l}\text { Endometrial cancer } \\
\text { Breast cancer }\end{array}$ & $\mathrm{r}_{\mathrm{s}}=-0.14, p=0.420$ & $\mathrm{r}_{\mathrm{s}}=-0.20, p=0.235$ \\
Ovarian cancer & $\mathrm{r}_{\mathrm{s}}=-0.00, p=0.969$ & $\mathrm{r}_{\mathrm{s}}=-0.01, p=0.856$ \\
Vulvar cancer & $\mathrm{r}_{\mathrm{s}}=0.06, p=0.748$ & $\mathrm{r}_{\mathrm{s}}=0.15, p=0.403$ \\
Cervical cancer & $\mathrm{r}_{\mathrm{s}}=-0.12, p=0.627$ & $\mathrm{r}_{\mathrm{s}}=-0.04, p=0.868$ \\
& $\mathrm{r}_{\mathrm{s}}=-0.07, p=0.723$ & $\mathrm{r}_{\mathrm{s}}=-0.02, p=0.924$ \\
\hline
\end{tabular}

\section{Discussion}

The aim of the study was to compare the $25(\mathrm{OH}) \mathrm{D}$ levels in patients with gynaecological cancers with those in patients with benign gynaecological disease. $25(\mathrm{OH}) \mathrm{D}$ is attracting attention because it seems to influence carcinoma and, also, internal ailment. Supplementation of $25(\mathrm{OH}) \mathrm{D}$ could reduce internal ailment, the incidence of carcinoma and improve outcomes (18, 19). The National Health and Nutrition Examination Survey defined a serum 25-hydroxyvitamin D concentration of $\leq 20$ $\mathrm{ng} / \mathrm{ml}(50 \mathrm{nmol} / \mathrm{l})$ as a deficiency level (20). The Department of Nutritional Sciences, University of Toronto mentioned an optimal value of $30 \mathrm{ng} / \mathrm{ml}(75 \mathrm{nmol} / \mathrm{l})(21)$.

Our study showed that the average level for all patients was $18.31 \pm 11.71 \mathrm{ng} / \mathrm{ml}$, indicating a vitamin D deficiency. 
The 25(OH)D levels in patients with a benign gynaecological disease were a slightly higher in comparison to patients with a gynaecological carcinoma. A Chinese study from 2015 to 2018 involving 4728 pregnant women found also a deficiency in vitamin $\mathrm{D}$ with levels ranging from $43.22 \pm 18.41 \mathrm{nmol} / 1$ in 2015 , to $39.3 \pm 15.1$ $\mathrm{nmol} / 1$ in 2016 and $36.6 \pm 17.0 \mathrm{nmol} / 1$ in 2017 (22). Streb et al. have obtained similar results, $25(\mathrm{OH}) \mathrm{D}$ levels were lower in patients with breast cancer than in the healthy group (23). As expected, the highest 25(OH)D levels were found in the summer and the lowest in spring with significant effects in both groups. Same results were shown following classification into quartiles. Analysis of each gynaecological tumor and seasonal comparison resulted in significant associations especially for breast, endometrial, and ovarian cancer. Hintzpeter et al. have also shown seasonal changes in serum 25(OH)D levels. They observed the lowest levels in March and the highest levels in June (24). A study from Demark with 3092 individuals reported the same seasonal variations (25). Acevedo et al. have found higher vitamin levels in breast cancer patients in summer than in winter (26).

A comparison of $25(\mathrm{OH}) \mathrm{D}$ levels and menopause status showed higher levels for post-menopausal women, but there was no significant association with any of the different parameters like benign/ malignant group, quartiles or tumor classification. Same results have been described in a study by Shriazi et al. (27). Scott et al. have reported an association with higher breast cancer risk among postmenopausal women; this relation was not valid for premenopausal women (28). Our analysis regarding age and vitamin D levels demonstrated a significant correlation in the malignant group and after subdivision, especially for breast cancer patients. Shirazi et al. have also found a positive correlation between age and 25(OH)D levels (27). A study from Japan has shown significantly lower levels for women under 30 years of age (29). The reason could be that older individuals take more supplements than younger ones.

As in our study, Shirazi et al. did not show a significant relation between vitamin D status and smoking (27). This result applied to all our examined groups. Brot et al. have shown a different outcome in a study involving 510 perimenopausal women $(50$ percent smokers $)$ with significantly reduced $25(\mathrm{OH}) \mathrm{D}$ levels (30). Cabaset et al., in a study with healthy pregnant women in their first trimester, found that former smokers had a smaller risk for low 25(OH)D levels (31).

We could not find a significant correlation between the grade of cancer and $25(\mathrm{OH}) \mathrm{D}$ levels. Imitaz et al. have obtained the same results indicating no significant association with the grade, state or hormone receptor status in a study of 90 breast cancer patients (32). In a case control study with ovarian cancer patients, Walentowicz-Sadlecka et al. have reported that a significant effect of the grade and 25(OH)D levels was missing as well (33). Another case control study with 78 breast cancer patients and 78 healthy women has reported a significant relationship between grade and 25(OH)D levels with lower levels in poorly differentiated tumors. They have also examined the relation between 25(OH)D levels and pre- and post-menopausal breast cancer patients. No statistically significant effects were observed (34).

\section{Conclusion}

An association was found between benign gynaecological disease and gynaecological cancers to vitamin D, although not all differences were significant. Additional studies are needed regarding the use vitamin D for prevention or therapy of cancers.

\section{Conflicts of Interest}

No conflicts of interest exist regarding this study.

\section{Authors' Contributions}

Study conception and design: Michael Friedrich; Acquisition of data: Laura Kolnsberg; Laboratory supply: Marion Riffelmann; Analysis and interpretation of data: Laura Kolnsberg; Drafting of manuscript: Laura Kolnsberg; Critical revision: Michael Friedrich.

\section{References}

1 Stöver I and Feyer P: Praxismanual Strahlentherapie. Springer Nature eBooks. 161-178; Springer Berlin Heidelberg, 2018.

2 Krebs in Deutschland Häufigkeiten und Trends. Arbeitsgemeinschaft Bevölkerungsbezogener Krebsregister in Deutschland, in Zusammenarbeit mit dem Robert-Koch-Institut, 4. überarbeitete, aktualisierte Ausgabe. Saarbrücken, 2004.

3 FerlayJ: Globocan 2000. International Agency for Research on Cancer. World Health Organisation, Genf, 2011.

4 Reinthalle A and Leodolter S: Chirurgische Onkologie. Vulvakarzinom Part 2: 441-447, 2008.

5 Kurzeder C, Sauer G and Kreienberg R: Epidemiology of endometrial cancer. Gynäkologe 40: 10-13, 2007.

6 Mendivil A, Schuler KM and Gehrig PA: Non-endometrioid adenocarcinoma of the uterine corpus: a review of selected histological subtypes. Cancer Control 16(1): 46-52, 2009. PMID: 19078929. DOI: $10.1177 / 107327480901600107$

7 Creasman WT: Prognostic significance of hormone receptors. Cancer 71: 1467-1470, 1993. PMID: 8431882. DOI: 10.1002/ cncr.2820710411

8 Petru E, Fink D, Köchli OR and Loibl S: Praxisbuch gynäkologische Onkologie 5. Auflage: 103-105, 2019.

9 Petru E, Fink D, Köchli OR and Loibl S: Praxisbuch gynäkologische Onkologie 5. Auflage: 70, 2019.

10 Engelsen O: The relationship between ultraviolet radiation exposure and vitamin D status. Nutrients 2(5): 482-495, 2010. PMID: 22254036. DOI: 10.3390/nu2050482 
11 Thomas L: Labor und Diagnose. Indikation und Bewertung von Laborbefunden für die medizinische Diagnostik. 8. Aufl. Frankfurt/Main: Th-Books Verl.-Ges, 403, 2012.

12 Olmos-Ortiz A., Avila E, Durand-Carbajal M and Díaz L: Regulation of calcitriol biosynthesis and activity: focus on gestational vitamin D deficiency and adverse pregnancy outcomes. Nutrients 7(1): 443-480, 2015. PMID: 25584965. DOI: $10.3390 /$ nu 7010443

13 Herold G: Innere Medizin 2008. Eine vorlesungsorientierte Darstellung unter Berücksichtigung des Gegenstandskataloges für die ärztliche Prüfung; mit ICD 10-Schlüssel im Text und Stichwortverzeichnis. Köln: 704-705, 2008.

14 Colonese F, Laganà A.S, Colonese E., Sofo V, Salmeri F.M, Granese R and Triolo O: The pleiotropic effects of vitamin D in gynaecological and obstetric diseases: an overview on a hot topic. BioMed Res Int 2015: 986281, 2015. PMID: 26000308. DOI: $10.1155 / 2015 / 986281$

15 Salehin D, Haugk C, Thill M, Cordes T, William M, Hemmerlein B and Friedrich M: Vitamin D receptor expression in patients with vulvar cancer. Anticancer Res 32(1): 283-289, 2015. PMID: 22213317.

16 Ma Y, Zhang P, Wang F, Yang J, Liu Z and Qin H: Association between vitamin $\mathrm{D}$ and risk of colorectal cancer: a systematic review of prospective studies. J Oncol 29(28): 3775-3782, 2011. PMID: 21876081. DOI: 10.1200/JCO.2011.35.7566

17 O'Brien KM, Sandler DP, Taylor JA and Weinberg CR: Serum vitamin D and risk of breast cancer within five years. Environ Health Perspect 125(7): 077004, 2017. PMID: 28728134. DOI: 10.1289/EHP943

18 Feldman D, Krishnan AV, Swami S, Giovannucci E and Feldman BJ: The role of vitamin $D$ in reducing cancer risk and progression. Nat Rev Cancer 14(5): 342-357, 2014. PMID: 24705652. DOI: $10.1038 / \mathrm{nrc} 3691$

19 Ekmekcioglu C, Haluza D and Kundi M: 25-Hydroxyvitamin D Status and Risk for Colorectal Cancer and Type 2 Diabetes Mellitus: A systematic review and meta-analysis of epidemiological studies. Int J Environ Res Public Health 14(2), 2017. PMID: 28134804. DOI: 10.3390/ijerph14020127

20 Forrest KY and Stuhldreher WL: Prevalence and correlates of vitamin D deficiency in US adults. Nutr Res 31(1): 48-54, 2011. PMID: 21310306. DOI: 10.1016/j.nutres.2010.12.001

21 Vieth R: What is the optimal vitamin D status for health? Prog Biophys Mol Biol 92(1): 26-32, 2006. PMID: 16766239. DOI: 10.1016/j.pbiomolbio.2006.02.003

22 Yin WJ, Tao RX, Zhang Y, Jiang XM, Jin D and Yao MN: Trends analysis of vitamin D status among pregnant women in Hefei during 2015-2017. Zhonghua Yu Fang Yi Xue Za Zhi 53(9): 947950, 2019. PMID: 31474080. DOI: 10.3760/cma.j.issn.02539624.2019.09.016

23 Streb J, Glanowska I, Streb A, Szpor J, Kryka K and Potocki P: The relationship between breast cancer treatment, tumour type and vitamin D level in pre- and postmenopausal women. Neuro Endocrinol Lett 38(6): 437-440, 2017. PMID: 29298285.

24 Hintzpeter B, Mensink GBM, Thierfelder W, Müller MJ and Scheidt-Nave C: Vitamin D status and health correlates among German adults. Eur J Clin Nutr 62(9): 1079-1089, 2008. PMID: 17538533. DOI: $10.1038 /$ sj.ejcn. 1602825
25 Hansen L, Tjønneland A, Køster B, Brot C, Andersen R, Cohen AS, Frederiksen K and Olsen A: Vitamin D status and seasonal variation among danish children and adults: A descriptive study. Nutrients 10(11), 2018. PMID: 30463277. DOI: 10.3390/ nu 10111801

26 Acevedo F, Pérez V, Pérez-Sepúlveda A, Florenzano P, Artigas $\mathrm{R}$, Medina $\mathrm{L}$ and Sánchez C: High prevalence of vitamin D deficiency in women with breast cancer: The first Chilean study. Breast (Edinburgh, Scotland) 29: 39-43, 2016. PMID: 27400446. DOI: $10.1016 /$ j.breast.2016.06.022

27 Shirazi L, Almquist M, Malm J, Wirfält E and Manjer J: Determinants of serum levels of vitamin D: a study of life-style, menopausal status, dietary intake, serum calcium, and PTH. BMC Womens Health 13: 33, 2013. PMID: 23945218. DOI: 10.1186/1472-6874-13-33

28 Bauer SR, Hankinson SE, Bertone-Johnson ER and Ding EL: Plasma Vitamin D levels, menopause, and risk of breast cancer. Medicine 92(3): 123-131, 2013. PMID: 23625163. DOI: 10.1097/MD.0b013e3182943bc2

29 Nakamura K, Nashimoto M, Matsuyama S and Yamamoto M: Low serum concentrations of 25-hydroxyvitamin D in young adult Japanese women: a cross sectional study. Nutrition 17(1112): 921-925, 2001. PMID: 11744341. DOI: $10.1016 / \mathrm{s} 0899-$ 9007(01)00662-1

30 Brot C, Jorgensen NR and Sorensen $\mathrm{OH}$ : The influence of smoking on vitamin D status and calcium metabolism. Eur J Clin Nutr 53(12): 920-926, 1999. PMID: 10602348.

31 Cabaset S, KriegerJP, Richard A; Elgizouli M, Nieters A; Rohrmann S and Quack Lötscher KC: Vitamin D status and its determinants in healthy pregnant women living in Switzerland in the first trimester of pregnancy. BMC Pregnancy Childbirth 19(1): 10, 2019. PMID: 30621626. DOI: $10.1186 / \mathrm{s} 12884-018-$ 2150-1

32 Imtiaz S, Siddiqui N, Raza SA, Loya A and Muhammad A: Vitamin D deficiency in newly diagnosed breast cancer patients. Indian J Endocrinol Metab 16(3): 409-413, 2012. PMID: 22629509. DOI: $10.4103 / 2230-8210.95684$

33 Walentowicz-Sadlecka M, Grabiec M, Sadlecki P, Gotowska M, Walentowicz P, Krintus M, Mankowska-Cyl A and Sypniewska G: $25(\mathrm{OH}) \mathrm{D} 3$ in patients with ovarian cancer and its correlation with survival. Clin Biochem 45(18): 1568-1572, 2012. PMID: 22884489. DOI: 10.1016/j.clinbiochem.2012.07.110

34 Karthikayan A, Sureshkumar S, Kadambari D and Vijayakumar C: Low serum 25-hydroxy vitamin D levels are associated with aggressive breast cancer variants and poor prognostic factors in patients with breast carcinoma. Arch Endocrinol Metab 62(4): 452-459, 2018. PMID: 30304110. DOI: 10.20945/23593997000000062
Received October 2, 2019

Revised October 30, 2019

Accepted October 31, 2019 